\title{
The Impact of the Epidemic Generated by the SARS-COV-2 Virus in the Context of the VUCA World
}

\author{
Mihaela MINCIU 1 \\ Răzvan Cătălin DOBREA ${ }^{2}$ \\ Camelia STĂICULESCU ${ }^{3}$ \\ Bogdan Ștefan STOICA ${ }^{4}$
}

\begin{abstract}
In a volatile, uncertain, complex and ambiguous business environment (VUCA environment) organizations often face changes, being forced to update their strategy in order to maintain or increase their competitive advantage. In the context of the SARS-CoV-2 pandemic, all organizations regardless of their area of activity had to devise a fast-track action plan so that they could continue their work even in a new world - an uncertain world with many changes, from one hour to another.

Therefore, the purpose of this paper is to reveal the connection between the VUCA business environment and the SARS-CoV-2 pandemic context, respectively the way in which organizational change analyzed through the VUCA world could influence the activity of organizations in the pandemic context.

In order to achieve these objectives, a systematic review was conducted. Starting from the present studies and researches, this paper aims to present the main components of the VUCA world and how they influence organizational change, the implications that the pandemic context had on the activity organizations, changes in the style of coordination and leadership of organizations caused by SARS-CoV-2, as well as the new skills and competencies that employees of organizations must acquire in order to cope with an insecure and complex business environment. The results showed that taking into account the aspects characteristic of the VUCA world can play a decisive role when a crisis situation arises, such as that created by SARS - CoV-2.
\end{abstract}

KEYWORDS: organizational change, transformation, SARS-CoV-2, VUCA

JEL CLASSIFICATION: $G 32, H 12, J 53$

\section{INTRODUCTION}

The business environment has suffered many changes in recent years, so organizations need to update their management system more and more often to respond to all challenges. The interest in studying all these critical situations specific to a volatile, uncertain, complex and ambiguous world - the VUCA world has grown with the appearance of the pandemic situation caused by coronavirus. The epidemic generated by the SARS-CoV-2 virus was a major shock to the European and world economy. The rapid and difficult to prevent transmission of the SARS-CoV-2 virus has affected financial markets, despite all the measures taken to manage the medical crisis.

\footnotetext{
${ }^{1}$ Bucharest University of Economic Studies, Romania, mihaela_minciu@yahoo.com, corresponding author

${ }^{2}$ Bucharest University of Economic Studies, Romania, razvan.dobrea@man.ase.ro

${ }^{3}$ Bucharest University of Economic Studies, Romania, camistaiculescu@yahoo.com

${ }^{4}$ Bucharest University of Economic Studies, Romania, stoica.bogdan@ yahoo.com
} 
The SARS-CoV-2 virus has affected a number of industries from mining, electronics, automobiles to transportation and logistics. The transformations that the COVID 19 epidemic created in the business environment were unexpected and difficult to manage because the interruptions of activity of some companies produced changes on the others, directly affecting the supply chain. Thus, many companies have faced and continue to face a deficit in terms of components needed for production. Given the pandemic context, states have had to take swift budgetary measures to develop/improve their health systems and to provide sectors, and implicitly small and medium-sized enterprises, that have been directly or indirectly affected by this crisis a support. Being an evolving situation, an unpredictable and difficult to understand situation economists have not provided accurate information on the negative effects that will be felt, but the data seem very worrying, given that the epidemic seems to be long lasting, taking on increasingly aggressive forms.

With the appearance of this crisis, which required for swift action by the authorities to minimize the negative impact on the living standards of the population, the concept of "VUCA world" has attracted more and more attention from researchers. VUCA is an acronym used by the US military to describe unpredictable situations after the end of the Cold War. Over the years this concept has been taken over by the business environment to explain the essential need of organizations to continuously adapt to changes in a system that is difficult to control. The VUCA world defines an extremely complex and ambiguous environment, an environment of the digital economy, in which organizations must quickly adapt to new models and techniques, in order to remain competitive in the market.

Therefore, this paper aims to describe the connection between the VUCA world and the pandemic context generated by the SARS-CoV-2 virus. Thus, if in the first part of the paper different theoretical aspects regarding the VUCA business environment and the epidemic caused by COVID-19 will be presented, in the next part all this information will be used to investigate the connection between the VUCA world and the coronavirus epidemic, as well as the effects of the VUCA world and the pandemic context on organizations, respectively the way in which organizations respond to them.

\section{LITERATURE REVIEW}

The spread of the coronavirus pandemic has caused an avalanche of changes in organizations. More and more managers say they are overcome by the situation, considering all local and global directives, as well as legislative and fiscal measures that stop the development and require for an update of action plans from day to day. Therefore, the managers consider that the organizations need to be more flexible, more innovative in terms of solutions to the problems they face, especially the unexpected ones related to human resources, respectively affecting their members, (outbreak of infectious diseases - COVID 19) and forces them to quickly make the transition to remote work and staff flow (Birona et al., 2020).

Thus, with the crisis generated by the SARS-CoV-2 virus, more attention was paid to the concept of "VUCA world". The acronym VUCA was adopted by the corporate world to describe today's world (Van Wynen \& Niemandt, 2020).

The VUCA world refers to the chaotic world in which we live (Bennett \& Lemoine, 2014a; Rabenu \& Tziner, 2018). Research suggests that VUCA may manifest in the short term in the form of sudden crisis events and may motivate people to cope with the associated stress by creating states of flow, attention, self-compassion, and learning opportunities (Moynihan, 
2008, 2009; Wickremasinghe, 2017; Bawa, 2020). In the VUCA business environment, nothing is certain - if before in an organization there was only one action plan that was followed in detail, now managers have to make periodic updates whenever they receive new information (Robertson, 2016). In other words, the term "VUCA" characterizes all the challenges that people have to face, both professionally and personally, in most situations having to make decisions quickly without having much time to analyze all future effects.

Volatility, the first component describes a world that is constantly changing, at a very high speed. More and more often the decision taken today in an organization, the next day proves to be no longer valid, because the rapid rhythm of change in the business environment (market fluctuations, the relationship between supply and demand, price changes, the appearance and disappearance of competitors), being almost impossible to identify the cause and effect. Volatility captures all the fluctuations and changes in the economy, socio-political and geopolitical indicating the difficulty of describing these events (Codreanu, 2016). Running a successful business requires first and foremost overcoming all obstacles in the business environment (Saleh \& Watson, 2017). In this context, the use of new technologies has a significant role, as they can provide information on market location (Cazabat, Belu, Popa \& Paraschiv, 2017)

For example, at the time of the pandemic, each company had to make a series of day-to-day decisions in order to protect employees and for the SARS-CoV-2 virus does not reach a higher rate of spread. Depending on industry the organizations have either continued their activity, reorganizing their entire system, taking into account all legislative regulations, or have ceased their activity for a certain period of time or in the worst case, they completely closed the activity being forced to withdraw from the market.

The second component, uncertainty reflects the lack of information related to the frequency and impact of changes in the environment (Bennett \& Lemoine, 2014b; Cousins, 2018). In the VUCA world it is very difficult to anticipate crisis situations, that may occur and implicitly their consequences. Moreover, in the VUCA business environment, the experience previously acquired by the managers and implicitly the employees of an organization is no longer a source of information, in order to solve problems because the situations are completely new. In the context of the pandemic situation, each company, in order to ensure the continuation of its business, had to adapt quickly to a new world, full of restrictions - a business world that it had not "known" before.

The next component of the VUCA world, complexity refers to the multitude of factors that must be taken into account when making a decision. When a problem arises, all causes must be identified and analyzed, both from outside and inside the organization (Sullivan, 2012; Kaivo-oja \& Lauraeus, 2018). If before a series of analyzes could be carried out within an organization on the basis of which the decisions taken could be grounded, this is no longer possible. In the context generated by the SARS-CoV-2 virus, managers had to make decisions as soon as possible so that all the organization's resources could be used efficiently, despite the fact that the COVID-19 epidemic generated major changes from day to day: the closure of certain sectors of activity, the imposition of certain rules on how to conduct business, the restriction of access to persons, etc. The VUCA world demands the emergence of new business models that pay much more attention to uncertain situations, new technologies and collaborative work.

Ambiguity, the last component of the VUCA world, refers to the fact that each situation can be viewed from several angles, so that the employees of an organization cannot only think in 
shades of "black" and "white". This is rendered by the inability of an organization's employees to provide "yes /no" answers, given the totality of decision alternatives that could prove to be truly functional depending largely on "how, when and where a butterfly flaps its wings" (Codreanu, 2016). Ambiguity reveals new situations, often characterized by new products, market strategies or technological innovation (Cousins, 2018).

The four characteristics of the VUCA world (volatility, uncertainty, complexity and ambiguity), which leaders of organizations must face in the pandemic context must be carefully managed and transformed into opportunities, so that every organization can overcome this crisis, without affecting the activity carried out (figure 1).

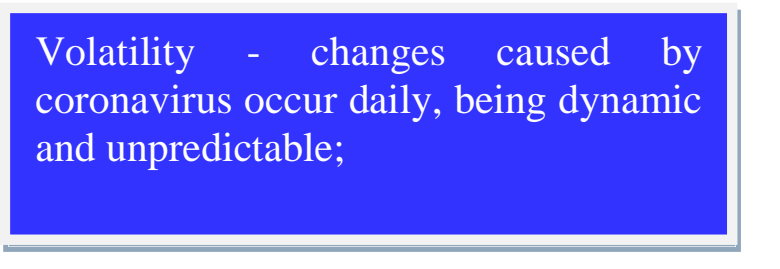

Uncertainty - no one can predict when the coronavirus pandemic will end or when an appropriate treatment schedule will be found;

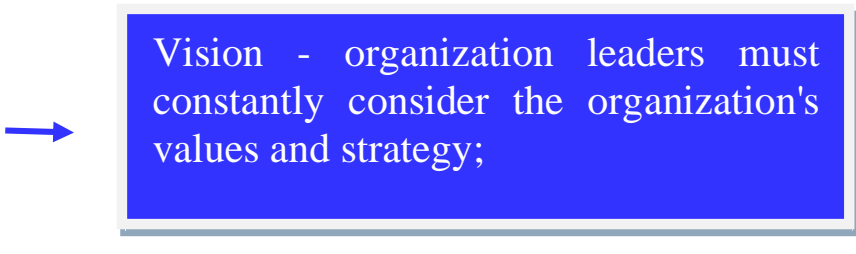

Understanding - during such an unpredictable environment, leaders of organizations must fully understand the changes that need to be made, as well as their impact on the business, in order to develop the right strategies;
Complexity - the pandemic context affected all aspects of life, in complex forms (health, social life, business environment);
Ambiguity - there is no single way for organizations to take to deal with all the challenges posed by the coronavirus epidemic.
Clarity - leaders of organizations must be able to explain each measure taken to employees and provide them with all the necessary support;
Adaptability and agility - organization leaders need to be agile and flexible so that they can re-evaluate the business environment and adopt a new strategy so that they can achieve their goal.

Figure 1. Components of VUCA world in SARS-CoV-2 pandemic context Source: adapted from Ghabour, E. (2020)

For an organization's employees to manage chaos, they must become open to change, adaptable (King, 2013). Traditionally, in a stable business environment, organizations have relied on previous experience, but given the ambiguity specific to the VUCA world, organizations must attract all stakeholders to the learning and innovation process (Felin \& Powell, 2016; Cousins, 2018). Thus, the leaders of an organization, especially in the pandemic context must become agile and create a culture that allows all employees to participate in the decision-making process, being necessary to achieve an innovation in the classical hierarchical system. 
In the VUCA world, as in the pandemic context generated by the SARS-CoV-2 virus, employees of organizations must acquire new skills and become flexible and able to develop strategies and short-term action plans, depending on the threats and opportunities, as the case.

\section{METHODOLOGY}

In order to identify the impact of the epidemic generated by coronavirus in the context of the VUCA world, a systematic search of the available articles and of the specialized paper was carried out, being researched the following areas: VUCA, components of the VUCA world, effects of the VUCA world on organizations, employee skills in the VUCA world, SARSCoV-2 pandemic context, impact of coronavirus epidemic on organizations, the threats of VUCA world and the pandemic context on the employees of an organization.

In order to collect the data, various articles and research published in economic journals were analyzed, studying how organizations had to adapt to change in order to overcome all obstacles that could pose a threat to them. Particular attention was also paid to webinars, national and international conferences where various topics related to the world of VUCA and the pandemic context generated by the SARS-CoV-2 virus were presented. Media articles and reports published by certain well-known companies in the field were also researched.

The search was conducted in October 2020, using the Web of Science, Scopus, ProQuest Central and Google Scholar databases. The following keywords were used: "COVID-19", "SARS-CoV-2", "coronavirus", "VUCA world", "volatility", "uncertainty", "complexity", "ambiguity", "organizational change", "pandemic context". Those studies that included the search terms in the title, keywords, abstract or body text were selected for analysis. Thus, 661 articles resulted. After the exclusion of recurring papers that were not written in English or Romanian, as well as studies which approached in a general way the concepts of "VUCA world" and "SARS-CoV-2", without highlighting their impact on organizations it reached a number of 30 articles that were studied in detail.

Thus, in the first part the authors present the concept of "VUCA world" and its connection with the epidemic caused by coronavirus, starting from its components, respectively: volatility, uncertainty, complexity and ambiguity. After each component was analyzed in parallel with the pandemic context generated by SARS-CoV-2, the authors study in the next part based on previous information how organizations react to the VUCA world and implicitly to the epidemic caused by coronavirus to continue their activity, even in difficult situations.

\section{RESULTS AND DISCUSSION}

The coronavirus epidemic has produced major changes in financial markets around the world, expecting significant effects on the global economy, considering all constraints. The VUCA business environment perfectly describes the current context, which is constantly changing, due to the SARS-CoV-2 virus. In order to survive in the new world, organizations had to quickly adopt a series of measures to continue their activity, respecting all legislative regulations.

The pandemic generated by COVID - 19 has caused a series of changes, in the sense that people need to improve their adaptability, both in their careers and in designing their own lives (Rudolph, 2017; Wen, Chen, Li, \& Gu, 2020). Organizations facing the realities of a constantly changing world, a COVID-19 world, are facing challenging demands that have never been met before: establishing the workforce at a distance, building the necessary 
capacity, in order to reorganizing work processes, supporting supply activities in difficulty, preparing employees to acquire new skills and competencies, closing and opening the business amid uncertainty (Worley \& Jules, 2020). In the pandemic context, efficient teamwork, which consists in solving problems accurately, frequently and in a timely manner, in order to achieve common goals, represent a factor that can influence an organization's position in the market (Nemblard, Burns \& Shortell, 2020; Berg, 2020).

Given the rapid spread of this virus around the world, while the scientific community is battling the SARS-CoV-2 virus by taking a number of preventive measures and trying to find a treatment for it, managers need to do the same, so that the economic effects of the crisis to be minimal (Seetharaman, 2020). The pandemic context is an unprecedented test for organizations around the world. The COVID-19 epidemic has primarily disrupted supply chains, and with all the restrictions imposed by each state, supply chain disruptions are reaching an alarming level (Karmaker et al., 2020).

The study conducted by Darnhofer (2020) revealed that in Austria in mid-March a series of measures were adopted that affected all aspects of daily life, so that the activity of farmers do not be interrupted: the creation of online platforms to connect farmers with citizens, in the conditions of overcoming the existing blockages in the supply chains, offering support to farmers, considering that the agricultural workers could no longer enter in the country, attracting volunteers, etc. Therefore, there is a great need for the business environment to explore new ways / factors to support the supply chain against global disruptions (Karmaker et al., 2020; Remko, 2020).

The world we live in is an era of a digital revolution that determines a series of important changes for each economy (Titan, Burciu, Manea \& Ardelean, 2014).

The coronavirus pandemic has forced many companies to make a number of organizational changes, replanning key elements of their strategy, using technology to continue their operational processes (Dwivedia, et al., 2020). A study conducted by experts from the consulting company Frames at the request of Factory 4.0 in a sample of 300 Romanian companies from different industries (agriculture, energy, financial services, IT, etc.) through online questionnaires, telephone interviews, in March 2020 it revealed that most of the companies (over 70\%) did not have a strategy for situations such as the pandemic context caused by the SARS-CoV-2 virus. Only $11 \%$ of the 300 companies said they had developed an action plan to continue the business.

Regarding the main problems they faced in the current situation, most companies reported: financial blockages, supply problems, price increases. Also, most of the surveyed companies stated that they do not have sufficient stocks in order to cover a possible syncope in the supply chain.

Another survey conducted by MKOR Consulting at the level of 243 companies in Romania (2\% NGOs, $4 \%$ other types of organization, 5\% multinational companies, $89 \%$ entrepreneurial businesses), in April revealed that over $91 \%$ of companies are directly affected by the pandemic context. Among the most visible results of the epidemic caused by the SARS-CoV-2 virus are the decrease in turnover and the negative impact generated by the suspension of activity, the most affected being microenterprises.

Moreover, the study conducted by AMCOR at the level of the Romanian consulting market in the period 2019-2020, highlighted the fact that in 2020, over $40 \%$ of companies offering management consulting services estimate a decrease in turnover, having in view the context of the SARS-CoV-2 pandemic. Among the measures adopted to manage the crisis situation 
are: allocating financial funds to companies, amending the legislation on work schedule (work from home, telework), extending deadlines for payment of taxes and contributions, providing assistance to enterprises in difficulty.

Given the totality of the negative effects generated by the coronavirus epidemic, it can be stated that the early adaptation of the managers of an organization to the VUCA world determines a much more efficient management of a crisis situation. The figure below describes the connection between the VUCA world and the pandemic context created by the SARS-CoV-2 virus (figure 2).

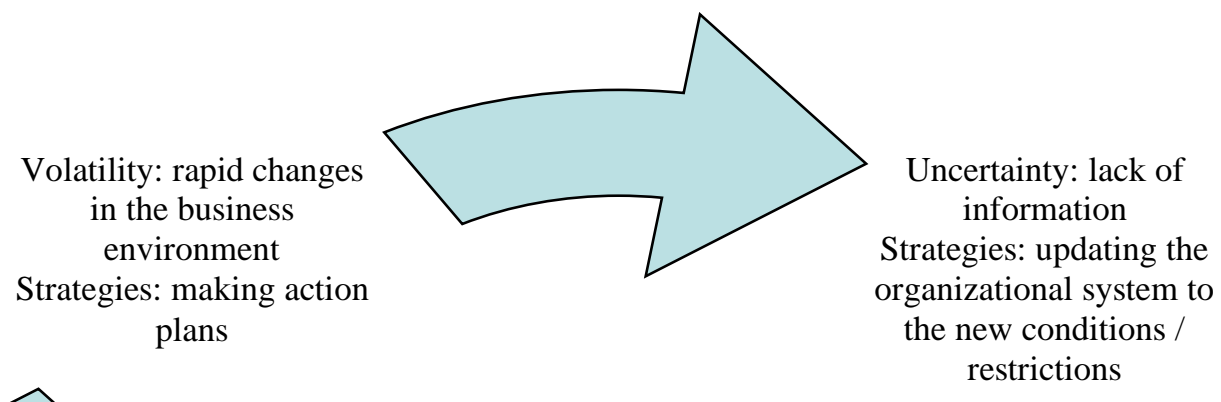

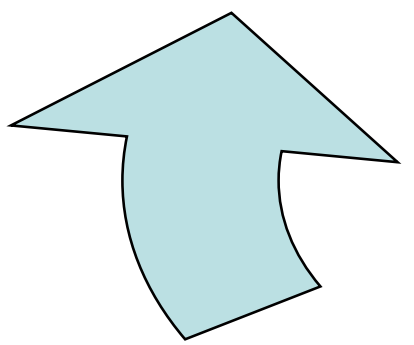

Ambiguity: analysis of situations from several points of view

Strategies: agility innovation, technological progress

\section{VUCA WORLD AND THE SARS-CoV-2 PANDEMIC CONTEXT}

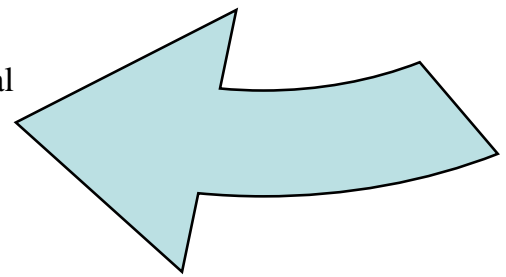

Complexity: the multitude of factors that influence the managerial system Strategies: efficient use of resources

Figure 2. The link between the VUCA world and the coronavirus epidemic Source: the authors' own contribution

The lack of response strategies in the face of such crisis situations, to which is added the reduced digitalization of production and business processes, which would allow managers to organize the firm's activity even remotely are the main causes leading to blockages. Also, employees' reluctance to change and how they handle a situation that may represent a threat to the organization they belong, play a crucial role in effectively managing new contexts, which can generate a number of changes.

\section{CONCLUSIONS}

The VUCA world refers to a chaotic environment, in which things become more and more unpredictable, often requiring a series of updates to the organizational system for a company to continue its activity, even at the time of a crisis such as the one caused by the SARS-CoV-2 virus. The coronavirus pandemic has brought a number of changes to organizations around 
the world, especially because of the speed with which it has spread. Thus, many organizations had to react very quickly and learn to continue their activity in a changed environment, given all the legal constraints, in some cases companies being forced to stop their activities.

The information analyzed showed that most organizations were directly affected by the epidemic caused by coronavirus because they had not established action plans for such crisis situations and also their employees were not prepared to adapt so quickly to a major change. The government also has a decisive role to play when a situation arises that directly or indirectly affects organizations, by all the measures that it adopts in order to support the affected enterprises. Therefore, adapting to the VUCA world and to the way of run a business in this new world is an important step for every organization as they become much better prepared and can manage more efficiently the crisis situations that may arise.

\section{REFERENCES}

Asociatia Consultantilor in Management din România (2020). Piața de consultanta in management din Romania in perioada 2019-2020, Retrieved October 8, 2020 from: https://amcor.ro/

Bawa, P. (2020). Learning in the age of SARS-COV-2: A quantitative study of learners' performance in the age of emergency remote teaching. Computers and Education Open, 1 (100016), 1-10, doi: https://doi.org/10.1016/j.caeo.2020.100016

Bennett, N., \& Lemoine, J. (2014a). What VUCA really means for you. Harvard Business Review, 92(1/2), 27-27.

Bennett, N., \& Lemoine, J. (2014b). What a difference a word makes: Understanding threats to performance in a VUCA world. Business Horizons, 57(3), 311-317.

Berg, S. (2020). COVID-19 Test Shortage: How a Clinic Stayed Local for Solutions. Retrieved October 8, 2020 from https://www.ama-assn.org/practice-management/ sustainability/covid-19-test-shortage-how-clinic-stayed-local-solutions

Birona, M., De Cierib, H., Fulmerc, I., Lind, C-H., Mayrhofere, W., Nyfoudif, M., . . . Sun, J. M. (2020). Structuring for innovative responses to human resource challenges: a skunk works approach. Human Resource Management Review, 1-16, [100768] doi: https://doi.org/10.1016/j.hrmr.2020.100768, 1-16.

Cazabat, G., Belu, M. G., Popa, I., \& Paraschiv, D. M. (2017). Models and practice of retail location on the Romanian market. Amfiteatrul Economic, 19 (45), 493-508.

Codreanu, A. (2016). A VUCA action framework for a VUCA environment. Leadership challenges and solutions. Journal of Defence Resources Management, 7 (2), 31-37.

Cousins, B. (2018). Design thinking: organizational learning in VUCA environments. Academy of Strategic Management Journal, 17 (2), 1-18.

Darnhofer, I. (2020). Farm resilience in the face of the unexpected: lessons from the COVID-19 pandemic, 37, 605-606, doi: https://doi.org/10.1007/s10460-020-10053-5.

Dwivedia, Y., Hughesa, L., Coombsb, C., Constantiouc, I., Duand, Y., Edwardse, J. S., . . . Upadhyay, N. (2020). Impact of COVID-19 pandemic on information management research and practice: Transforming education, work and life. International Journal of Information Management, 55, 1-20, doi: https://doi.org/10.1016/j.ijinfomgt.2020.102211.

Felin, T., \& Powell, T. (2016). Designing organizations for dynamic capabilities. California Management Review, 58 (3), 78-96.

Frames, (2020) Efectele coronavirusului, Retrieved October 8, 2020 from http://framesmedia.ro/ blog/ efectele -coronavirusului-peste-70-dintre-companii-nu-au-ostrategie-pentru-astfel-de-situatii/.

Ghabour, E. (2020), A New VUCA Model to Train Leaders to Manage Through COVID-19 and Beyond, Retrieved October 8, 2020 from https://trainingindustry.com/articles/ leadership/a-new-vuca-model-to-train-leaders-to-manage-through-covid-19-and-beyond/. 
Kaivo-oja, J. R., \& Lauraeus, T. I. (2018). The VUCA approach as a solution concept to corporate foresight challenges and global technological disruption. Foresight, 20, 27-49, doi:10.1108/FS-06-2017-0022.

Karmaker, C. L., Ahmed, T., Ahmed, S., Ali, S. M., Moktadir, M. A., \& Kabir, G. (2020). Improving supply chain sustainability in the context of COVID-19 pandemic in an emerging economy: Exploring drivers using an integrated model, Sustainable Production and Consumption, 26, 411-427, doi: https://doi.org/10.1016/j.spc.2020.09.019.

King, J. (2013). Managing chaos (as usual). Computerworld (47), 12-17.

Moynihan DP. (2008). Learning under uncertainty: Networks in crisis management. Public Administration Review, 68 (2), 350-365, doi: 10.1111/j.1540-6210.2007. 00867.x.

Moynihan DP. (2009). From Intercrisis to Intracrisis learning. Journal of Contingencie sand Crisis Management; 17(3), 189-98, doi: https://doi.org/10.1111/j.14685973.2009.00579.x.

Nemblard, I., Burns, L., \& Shortell, S. (2020). Responding to Covid-19: lessons from management research. Catalyst Non - Issue Content 1 (2), 1-7, doi: 10.1056/CAT.20.0111.

Oancea, D. (2020) Ce indică studiile firmei de consultanţă financiară MKOR Consulting, Retrieved October 8, 2020 from https://www.zf.ro/companii/ce-indica-studiile-firmei-deconsultanta-financiar a-mkor-consulting-19118354.

Rabenu, E., \& Tziner, A. (2018). Adapting to the New Era: Necessary Steps for Advancing a Robust Science. Amfiteatru Economic, 20 (48), 470-476, doi: 10.24818/EA/2018/48/470.

Remko, V. H. (2020). Research opportunities for a more resilient post-COVID-19 supply chain - closing the gap between research findings and industry practice. International Journal of Operations \& Production Management, 40, (4), 341-355, doi: https://doi.org/10.1108/IJOPM-03-2020-0165.

Robertson, D. (2016). Talent the differentiator. Training Journal, 33, 34-35.

Rudolph, C. W. (2017). Career adaptability: a metaanalysis of relationships with measures of adaptivity, adapting responses, and adaption results. Journal of Vocational Behavior, 98, 17-34, doi: 10.1016/j.jvb.2016.09.002.

Saleh, A., \& Watson, R. (2017). Business excellence in a volatile, uncertain, complex and ambiguous environment (BEVUCA). The TQM Journal, 29 (5), 705-724.

Seetharaman, P. (2020). Business models shifts: Impact of Covid-19, International Journal of Information Management, 54, 1-4.

Sullivan, J. (2012). VUCA: the new normal for talent management and workforce planning. Retrieved from ERE Recruiting Intelligence: https://www.ere.net/vuca-the-new-normalfor-talent-management-and-workforce-planning/.

Titan, E., Burciu, A., Manea, D., \& Ardelean, A. (2014). From traditional to digital: the labour market demands and education expectations in an EU context. Procedia Economics and Finance, 10, 269-274.

Van Wynen, S., \& Niemandt, C. (2020). Leading in the certainty of uncertain times . HTS Teologiese Studies/Theological Studies, 76 (2), 1-10, doi: https://doi.org/10.4102 /hts.v7 $6 \mathrm{i} 2.6114$.

Wen, Y., Chen, H., Li, K., \& Gu, X. (2020). The Challenges of Life Design Counseling in the Times of the Coronavirus Pandemic (COVID-19). Frontiers in Psychology, 11 (1235), 15, doi: https://doi.org/10.3389/fpsyg.2020.01235.

Wickremasinghe, N. (2017). It's not my fault but it is my problem: The role of self compassion in a VUCA world. Retrieved October 8, 2020 from https://www.linkedin.com/pulse/its-my-fault- problem-role-self-compassion-vuca-worldwickremasinghe/

Worley, C. G., \& Jules, C. (2020). COVID-19's Uncomfortable Revelations About Agile and Sustainable Organizations in a VUCA World. The Journal of Applied Behavioral Science 56 (3), 279-283, doi: https://doi.org/10.1177/0021886320936263. 